\title{
TTR
}

Traduction, terminologie, re?daction

\section{Anthony Pym, Miriam Shlesinger and Zuzana Jettmarová (ed.). Sociocultural Aspects of Translating and Interpreting. Amsterdam/Philadelphia, John Benjamins Publishing Company, 2006, 255 p.}

\section{Denise Merkle}

Volume 19, numéro 2, 2e semestre 2006

Traduire les Amériques

Translating the Americas

URI : https://id.erudit.org/iderudit/017832ar

DOI : https://doi.org/10.7202/017832ar

Aller au sommaire du numéro

Éditeur(s)

Association canadienne de traductologie

ISSN

0835-8443 (imprimé)

1708-2188 (numérique)

Découvrir la revue

Citer ce compte rendu

Merkle, D. (2006). Compte rendu de [Anthony Pym, Miriam Shlesinger and Zuzana Jettmarová (ed.). Sociocultural Aspects of Translating and Interpreting. Amsterdam/Philadelphia, John Benjamins Publishing Company, 2006, 255 p.] TTR, 19(2), 255-258. https://doi.org/10.7202/017832ar

Tous droits réservés () TTR: traduction, terminologie, rédaction Les auteurs, 2008
Ce document est protégé par la loi sur le droit d'auteur. L'utilisation des services d'Érudit (y compris la reproduction) est assujettie à sa politique d'utilisation que vous pouvez consulter en ligne.

https://apropos.erudit.org/fr/usagers/politique-dutilisation/ 
$\mathrm{Au}$ début de son ouvrage, l'auteure nous laisse entendre qu'elle mettra en évidence dans quelle mesure le traducteur a respecté les principes qui lui sont si chers en tant que critique d'œuvres littéraires. Or, l'auteure invite plutôt le lecteur à tirer lui-même ses conclusions au fil de sa lecture. Ce sera notre seule réserve.

En conclusion, cet ouvrage, agrémenté de repères biographiques sur le critique-traducteur qu'est Giacomo Debenedetti, laisse entrevoir sa vision de l'œuvre de Proust et illustre à quel point sa traduction de Swann représente un exemple de sa recherche de l'esthétisme. Ayant su distiller près d'un millénaire de traduction littéraire, Debenedetti déploie dans sa traduction un style sur lequel le temps n'a pas d'emprise, un style à la fois nouveau et fortement empreint de la traduction séculaire de la littérature classique italienne, un style dans lequel la recherche d'un temps perdu révèle les horizons d'une nouvelle ère littéraire.

\section{Marco A. Fiola Université Ryerson}

Anthony Pym, Miriam Shlesinger and Zuzana Jettmarová (ed.). Sociocultural Aspects of Translating and Interpreting. Amsterdam/Philadelphia, John Benjamins Publishing Company, 2006, 255 p.

This edited collection of 17 selected papers from the "Translation Targets Conference", organised by Charles University in Prague in September 2003, is a valuable contribution to the growing interest in the "social turn" in Translation Studies. Authors from a broad spectrum of sociocultural and political traditions-Canada, Europe (Austria, Belgium, Finland, Italy, Portugal, Spain, The Netherlands, United Kingdom), former USSR countries (Latvia, Romania) and Indiapresent case studies that expose translation and interpreting problems within their sociocultural context. One of the editors, Anthony Pym, precedes the papers with a thorough introduction to concepts discussed in the respective chapters and suggestions for future research. He notes the growing shift of interest in Translation and Interpreting Studies from the text to the social agent, from a sociology of language to a focus on "mediators and their social contexts" (p. 3) and encourages researchers to resist "the simple binarisms that oppose one society (language, culture) to another, with the mediator on one side or the 
other." Research "should be able to perceive overlaps and complex positions" (p. 24). The volume is organised into eight sections: 1) Agents behind translation; 2) Social histories; 3) Perceived roles and values; 4) Interaction of inner and outer contexts; 5) Power relations disclosed; 6) Power distribution and cooperation; 7) Constructing systems; 8) The view from Interpreting Studies.

A unique contribution of this volume that draws on progress in Interpreting Studies is its emphasis on interpreters and interpreting in health services, immigration detention centres and asylum hearings, with one-third of the papers dealing with community interpreting and public-service interpreting (sections 6,7 and 8). Katrien Lannoy and Jan Van Gucht's empirical sociology paper presents quantitative data on the "Babel rebuilt" three-tier structure of translation services provided to social welfare institutions in Flanders. This is the most overtly sociological paper of the volume; however, as Pym observes "the conceptual leaps from the empirical data to the recommendations remain precarious" (p. 21). What is clear from many of the other Interpreting Studies papers, as Pym states in his "Foreword," is that contextual power relations are often more important than the mere rendering of the message (vii). For instance, Sonja Pöllabauer presents examples of Austrian interpreters within their Translationskultur (Prunč 1997) at asylum hearings. The interpreters are all female in the cases studied and tend to favour one-sided loyalty with the immigration officers who are respectively male. Their mediatory role is neither neutral nor transparent, and this of course impacts their ethical commitment as interpreters to represent the interests of asylum seekers. Guillermo R. Navarro Montesdeoca discusses power relations at an Immigrant Detention Centre in Spain in what are considered to be democratic communication situations but where cooperation and understanding are not the overriding goals and the interpreter is low in the hierarchy with all that relative powerlessness implies. Mette Rudvin's contribution stresses the importance of considering the degree to which institutional systems (e.g., health care system, legal system) are culture-bound in order to create shared meaning during triadic interpreter-mediated cross-cultural exchange. The author outlines problems that may result when there is friction between the role of a natural interpreter assigned to a family member in a health-care setting and one's personal/cultural identity in cases where, for example, source culture taboo subjects are broached. Nadja Grbić outlines the dramatic changes in assessing sign language interpreters in Styria (Austria) over the past ten years in tandem with the professionalization of the sector 
through the development of university training programmes and professional associations. Her sociological research shows that the "norms of this system are unstable and contingent" and, in Pym's words, "asks to what extent the resulting network constitutes a social system" (a "common construction of reality") (p. 20). This section and the volume concludes with a paper by Franz Pöchhacker that, in keeping with the community(-based) focus of the five preceding papers located between traditional sociology and cultural analysis and their interest in the social contexts in which interpreters work, argues in favour of the "social turn" in Interpreting Studies marked by the International Conference on Interpreting Studies at Forlì in late 2000 (p. 231) and derived from the recognition that interpreting is not limited to conference interpreting. These papers complement the eleven other papers that focus on translators as social agents in primarily literary settings (sections 1-5).

Stella Linn examines the role that various agents played in conditioning the fluctuation of literary translation flows from the minor language Dutch into Spanish from 1950 to 2000. By drawing on the correspondence of two translators, Pekka Kujamäki analyses how primarily ideological norms informed the translation of Finnish literature in German during the 1920s and the rise of the Third Reich. Gaby Thomson-Wohlgemuth's contribution is a fascinating study of the role of censorship in the translation of English-language children's literature into German in the former East Germany. The following two papers deal with translations of Daniel Defoe's Robinson Crusoe. Maria Goreti Monteiro considers the first Portuguese translator of the work who self-censored material critical of the Catholic church as a result of negative experiences with the Inquisition, as his biography shows, followed by Rodica Dimitriu examining a number of Romanian translations and rewritings of the novel and looking for the possible social motivation-educational, entertainment, literary, political-behind them. Gabriel Louis Moyal provides interesting thoughts on the cultural-in particular, commercial-and ideological factors that influenced the translation of British literature in France from 1815 to 1848. Rita Kothari demonstrates that through social consensus translation into English can contribute to creating a separate cultural identity for Gujarati culture in India. Agnès Whitfield's paper situates, in the sociocultural context of Canada-Québec political relations, the history of the reception of Hugh MacLennan's "cultural translation" Two Solitudes, as well as the history of the reception of the French and Québec translations of the novel. Daniel Gagnon deals with timely 
issues of hybridity and postcolonial writing practices, bilingual writing/translating and expatriate versus impatriate writing. Michaela Wolf's analysis of female and feminist translation in German-speaking countries-primarily Austria-situates empirical data within a theoretical framework inspired by the French sociologist Pierre Bourdieu. Ieva Zauberga demonstrates that, by disregarding government-dictated linguistic norms when they translate proper nouns in travel guides for their compatriots, translators in Latvia are all but subservient agents in global communications.

The contributions serve to highlight Pym's warning that simple sociological or social approaches with their emphasis on social interaction to the exclusion of cultural products will invariably neglect the object of study in Translation and Interpretation Studies, namely the translated text or the interpreted message. As many of the papers have shown, what is needed is a combined social and cultural analysis, with a "conceptual frame located somewhere between the whole of society and the linguistic situation, between traditional sociology and closerange cultural analysis" (p. 22). Pym concludes his "Introduction: On the social and the cultural in translation studies" by affirming that the "most problematic relations of today's world are between cultures. To model those problems is our first step toward solving them" (p. 25). It is clear that this very useful book goes well beyond theoretical abstractions and parochial disciplinary concerns; the turn towards social and cultural approaches to the study of communication exchanges between different sociocultural groups based on case studies could improve our understanding of the root sources of miscommunication and contribute positively to our search for solutions. The book is therefore of obvious interest not only to translation and interpreting scholars, but also to all readers interested in the mechanics of intercultural/social communication.

\section{Denise Merkle Université de Moncton}

\section{Sherry Simon. Translating Montreal: Episodes in the Life of the Divided City, McGill-Queen's University Press, 2006, 280 p.}

This is not a tale of two cities nor indeed a tale of one city with two tales. It is a book about cities that have many tales to tell even if the focus is firmly and knowledgeably on Montreal. Mostar, Prague, 